\title{
'State-of-the-art' of building integrated photovoltaic products
}

\author{
Isabel Cerón ， E. Caamaño-Martín , F. Javier Neila
}

\begin{abstract}
A B S T R A C T
During the last decades, the photovoltaic (PV) modules and their associated architectural materials are increasingly being incorporated into the construction of the building envelope such as façade, roof and skylights in the urban centers.

This paper analyzes the-state-of-the-art of the PV elements and construction materials which are advertised as BIPV-products at the most important companies in the world. For this purpose 136 companies and 445 PV elements have been investigated and analyzed from a technical and architectural point of view. Also, the study has been divided into two main groups according to industry which producing the product: BIPV-Modules, which comes from the PV modules manufacturers and consist of standard PV-modules with some variations in its aesthetic features, support or dimensions; and PVConstructions Elements, which consist of conventional constructive elements with architectural features intentionally manufactured for photovoltaic integration. In advance for conclusions, the solar tile is the most common PV-constructions element, the Si-crystalline is the most widely used PV technology, and the BIPV-urban furniture is the fastest growing market experienced in recent years. However, it is clear the absences of innovative elements which meet at the same time both the constructive purpose as the quality standards of PV technology.
\end{abstract}

\section{Introduction}

Over recent decades numerous applications of PV technology in buildings have emerged, which have been studied to focusing on assess and reconsider technical PV aspects or totally architectural [1-5]. As a result of the lessons learned, the constructive application of the PV technology like consolidated form has been taken; this is nowadays a clearly defined market.

In terms of manufacturing matter there is still a long way to go and many challenges lie ahead. The evolution of PV technology and the development of new materials and building components are fundamental pieces in this work. Both, PV sector and construction industry must work together and join their experiences and knowledge in order to develop innovative elements, which in turn comply with all regulations and standards of quality and in accordance with photovoltaic engineering competences. Under this context, in Europe three fundamental aspects must be fulfilled according to the construction regulations: the technical quality (PV technology, constructive characteristics and functional), the deference for the environment (energy efficiency and health), and, the guarantee and safety in the use of the buildings' materials [6].

However, from architect's point of view the formal aspects of the materials are as important as the physical and functional integration [7]. Thus, the concept of 'aesthetic quality' arises like unscientific parameter and more subjective to consider in the system [8]. Own definitions of the PV application have been made in order to address the PV element from application point of view on the building, such as a conventional material of construction. According to Technical Building Code of Spain [9] two solutions can be suitable: architectural integrated PV elements or overlapping PV modules. Those concepts are also defined by several authors in the bibliography [10-12].

- Building Integrated Photovoltaic BIPV, which have dual functionality; replace the conventional elements of construction and generate energy.

- Building Applied Photovoltaic BAPV, consist of PV elements whose installation is performed through an overlay of parallel modules to the envelope of the building.

This BIPV market review aims to show all the parameters involved in the process of architectural integration of PV technology: 
the aesthetic possibilities, the Architectural functions, PV technology, security conditions, support structure and potential applications etc., which covers a wide range of BIPV products that are traded nowadays. Moreover, all of the BIPV elements reviewed are included.

In the following sections; research methodology (Section 2) and a comparative assessment is provided in terms of technical specifications and architectural integration aspects (Sections 4 and 5 respectively). Section 6 summarizes the main findings of the market study and identifies the challenges of architectural integration of PV technology as solar skins of buildings.

\section{Research methodology}

Overall, 445 BIPV elements manufactured or traded by 136 companies have been analyzed. The source of data have been collected from the suppliers (web pages, brochures and data sheets), the Photon International magazine updated to 2012 [13], the Swiss research center BIPV ISAAC-DACD-SUPSI focusing on development of architecturally integrated PV systems [14] and additional bibliography [15-19]. The information has been collected from each constructive element, PV module, or PV module family for the same manufacturer or trader, which has been classified according with relevant topics: product (image), technical information, quality and safety, and architectural integration.

Fig. 1 summarizes the products to be analyzed, there are two main groups that have been classified according their origin: BIPV modules (BIPV-M) and PV constructive elements (PV-CE).

\subsection{BIPV-modules}

The BIPV market offers the option of integrating PV modules (BIPV-M). The PV module is defined as an element made up of PV cells that connect together constitutes a PV power generation unit of the installation [20]. These are the first element used by solar industry to install PV systems. BIPV modules are especially designed for building integrating, according to the manufacturers have been considered (physical and/or aesthetical characteristics of interest from a constructive point of view). Further information is included [ANNEX A. BIPV-Modules].

\subsection{PV-constructive elements}

Many factors are involved when performing the architectural integration of PV systems: the PV engineering and energy performance, the function and architectural design, the thermal behavior, the light transmittance and the cost, so it is important to reach a compromise between them, while they should meet the safety requirements, both from the standpoint of electrical and architectural [21]. One way to accomplish this is to make up BIPV elements from its origin with PV technology, the idea has been adopted by construction materials companies, it has resulted PV constructive elements that constitute more innovative elements in terms of design and architectural functionality, some of them can be defined [22]: enclosure, shading, waterproofing, thermal insulation, acoustic insulation, finishing-buildings and lighting.

Roofs systems [ANNEX B. BIPV-Roof] and facades systems [ANNEX C. BIPV-Facade] are standardized products which marketed with fact sheet and installation manual own, and in many cases may be installed by unskilled staff. Urban furniture products [ANNEX D. BIPV-Urban Furniture] have a special functionality into architecture, and the PV technology aims is the self-consume [23]. Other custom-made products are elements which in general are accompanied by the technical advice and/or the manufacturer's installation [ANNEX E. BIPV-Custom Design]. The last two groups are only included to informational way.

\section{Distribution of BIPV market}

Fig. 2 shows a breakdown of 445 BIPV products surveyed (196 BIPV modules and 249 PV constructive elements). A large percentage of PV-CE is roofing systems, which is the simplest and most common application in the BIPV market. Urban furniture market has had high growth in recent years; the integration of PV technology in this sense is very useful due to the self-consumption of the system, being the most common application of pedestrian lighting, furthermore, the use of renewable energy sources generates a green image and civic used by some local authorities to produce social impact [24].

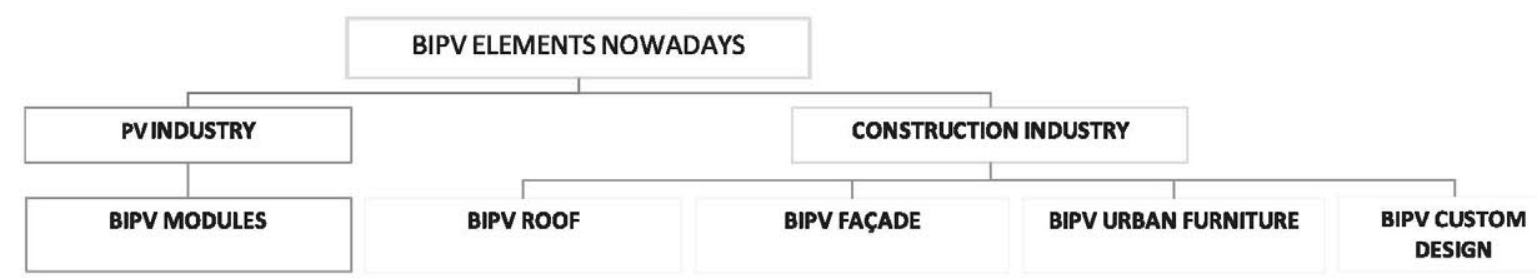

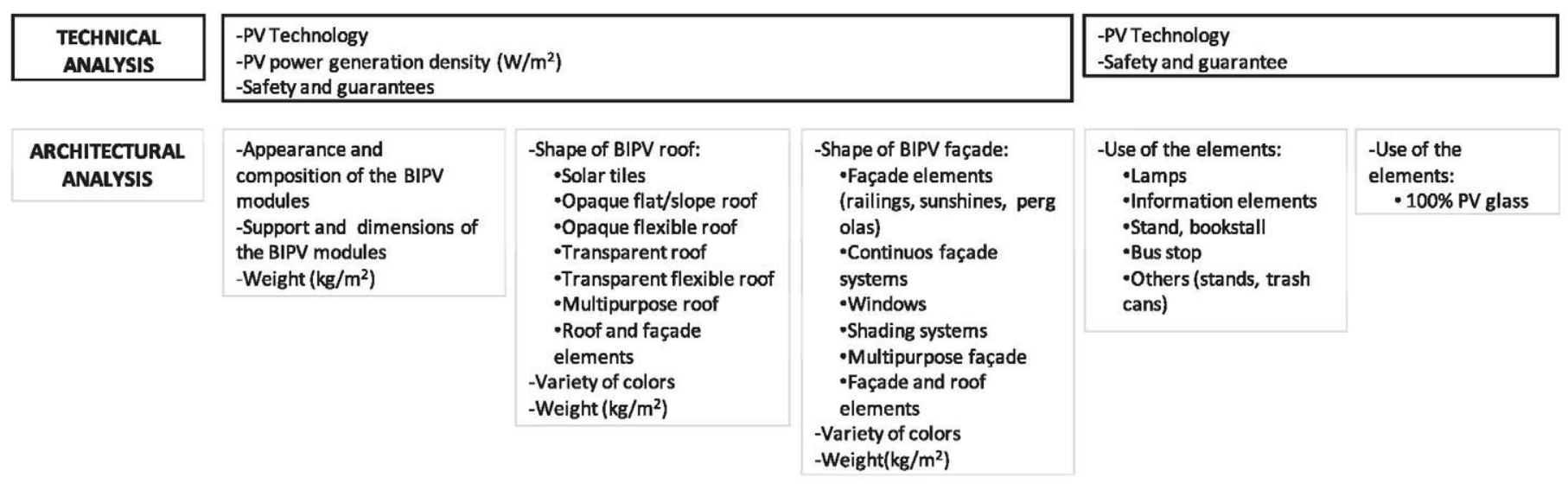

Fig. 1. Research methodology. 


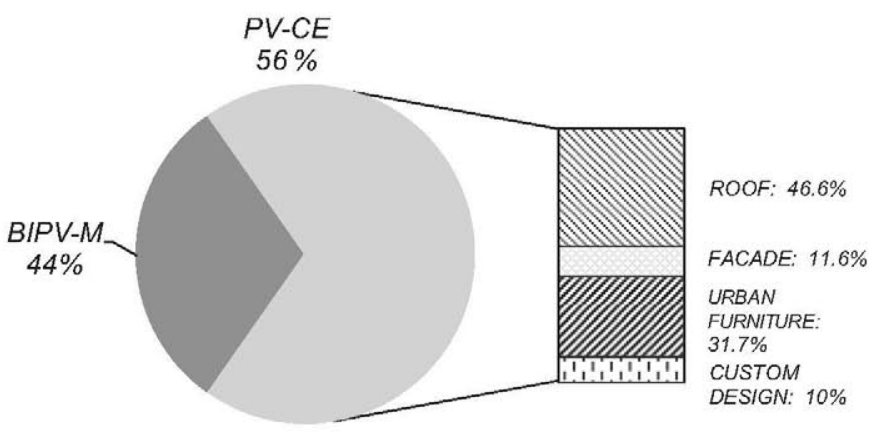

Fig. 2. Breakdown of BIPV market.

\section{Technical analysis}

\subsection{Basic concepts of efficiency of PV technology}

Power conversion efficiency $(\eta)$ is given by the efficiency of their solar cells and the physical layout of the PV element, and usually varies between a manufacturer and other. It is defined as the ratio between the power which is capable of generating the PV element and the amount of solar energy received, $\eta=P_{m} / E \times A_{c}$, where $P_{m}$ is the installed maximum power in $W$ or Wat-peak $(W p), E$ is the input light irradiance in $\mathrm{W} / \mathrm{m}^{2}$, and $A_{c}$ is the surface area of the PV element in $\mathrm{m}^{2}$. These values are measured by the manufacturers under a Standard Test Conditions STC (input light irradiance $1000 \mathrm{~W} / \mathrm{m}^{2}$, AM or Air Mass 1.5 spectrum of light, and $25^{\circ}$ temperature of the solar cells). Some typical efficiency ranges using conventional modules, according to its technology are shows in Table 1.

From a formal point of view, PV technology is usually classified into two main groups:

1) Crystalline Silicon (c-Si), PV elements which are manufactured through the interconnection of conventional $\mathrm{Si}$ wafers. Its main advantages are its high reliability in use demonstrated for decades and its high efficiency power conversion, these aspects provides at the BIPV facilities more reliability and the best occupation ratio by using more power installed (for the same used area) than those used by other technologies.

2) Thin-film (TFSC) is made by deposition of thin layers of semiconductor material allowing in order to obtain a thin, flat-plate glass (rigid) or flexible PV elements [25]. The main advantages are: thicknesses lower, wide range of integration possibilities, both geometrical and dimensional flexibility, different materials in which the PV cells can be deposited (glass, flexible metal or polymer), that is why itself occurs the transparency and flexibility.

Table 1

Efficiency rating of PV modules according to their cells technology.

\begin{tabular}{llc}
\hline Technology & & Efficiency \\
\hline Crystalline silicon (c-Si) & Si-mono & $14 \%-19 \%$ \\
& Si-multi & $12 \%-15 \%$ \\
Thin film solar cells 'TFSC' & HIT $^{\mathrm{a}}$ & $15 \%-19 \%$ \\
& $\mathrm{a}-\mathrm{Si}$ & $5 \%-7 \%$ \\
& $\mu \mathrm{c}-/ \mathrm{a}-\mathrm{Si}$ & $7 \%-9.5 \%$ \\
& $\mathrm{CIS}$ & $10 \%-13 \%$ \\
& $\mathrm{CIGS}$ & $11 \%-13 \%$ \\
& CdTe & $10 \%-12 \%$ \\
\hline
\end{tabular}

\footnotetext{
${ }^{a}$ Heterojunction with Intrinsic Thin Layer HIT.
}

According to these characteristics, the choice between one group and other, determines the way of integrating PV technology into construction' materials and consequently the final formal aspects.

\subsection{PV technology and industry}

As shown in Fig. 3, prevails today in the BIPV market conventional PV technologies such as crystalline silicon (Si-multi and $\mathrm{Si}$ mono) and amorphous silicon (a-Si). Multi-crystalline silicon ( $\mathrm{Si}$ multi) is by far the most widely used technology in BIPV modules. However, when comparing the results with a similar study in 2010 [26], has been the fastest-growing technology in BIPV applications is Mono-crystalline silicon (Si-mono), from $16.6 \%$ in 2010 to $37.2 \%$ in 2012. There are three reasons to explain this industry behavior: 1) manufacturing price of crystalline PV modules has decreased in recent years much faster than thin film PV modules [27], 2) extensive knowledge of crystalline PV technology, and its preferential use by manufacturers of conventional modules, and 3 ) developing of mounting systems for standard PV modules, either for general or particular use $[28,29]$. The use of thin-film is noticeably better among the PV-CE due to it can be take better advantage of the technology itself. In general, the industry experiences a paralysis at the moment, and thin-film has lost share in market growth, especially amorphous silicon (a-Si), from $24.2 \%$ BIPV-M in 2010 to $9.2 \%$ in 2012.

\subsection{Use of the PV technology}

Regarding possibilities of the use, Fig. 4 shows that the most widely used technology between the roofing elements is Monocrystalline (Si-mono), particularly on tiles: $95.5 \%$ are made up by this technology. The tiles are usually quite small, so it must be leveraged the high efficiency of technology. In addition, is preferred those of homogenous dark color, singularly between roofing manufacturers, who emphasize this aesthetics feature. In facade systems, most used technology is the amorphous silicon (a-Si) this is because the elements can be constructed like conventional facades: large sizes, small thickness and transparency possibilities;

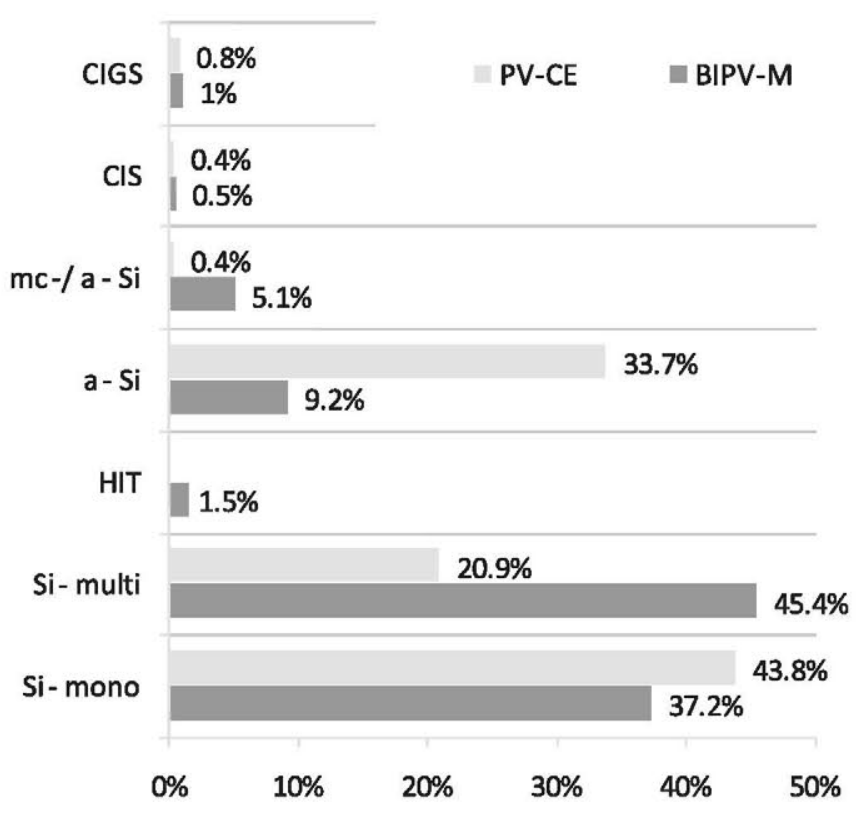

Fig. 3. Photovoltaic technologies of BIPV modules and PV constructive elements. 


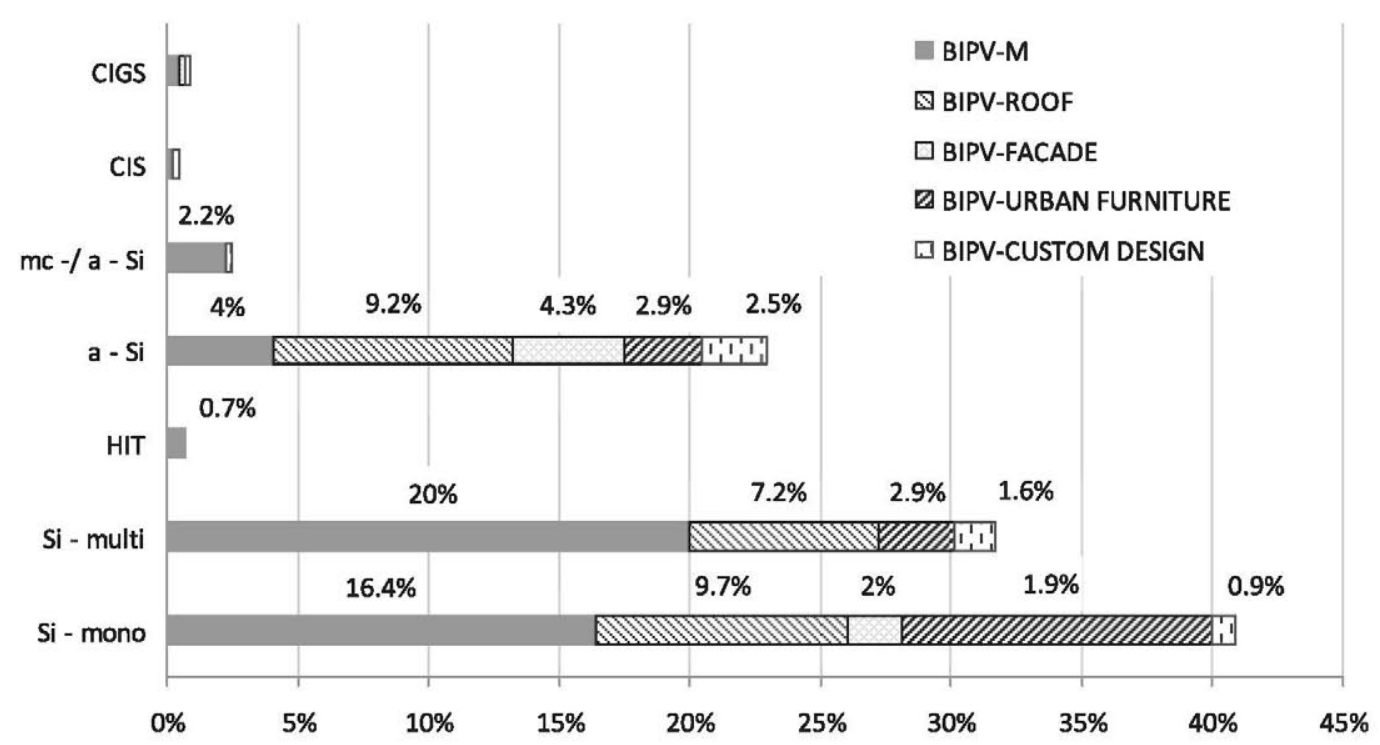

Fig. 4. Total distribution of PV technology according to possibilities to use of BIPV elements.

however, crystalline silicon also enables transparency possibilities by means of glass-to-glass and/or drilled solar cell already demonstrated in several BIPV applications.

\subsection{Power density of BIPV elements}

For the BIPV-M manufacturer, power generation efficiency is the most important parameter when marketing your product, unlike the PV-CE manufacturer, which sometimes does not include this information in its data sheets. Fig. 5 shows range of power density $\left(\mathrm{W} / \mathrm{m}^{2}\right.$ between installed power and occupied area) for BIPV elements.

More than $70 \%$ of BIPV-M are between $100 \mathrm{~W} / \mathrm{m}^{2}$ and $150 \mathrm{~W} / \mathrm{m}^{2}$ range of the power density, this is due mainly to the following; firstly fully take advantage of the element surface in order to collect the maximum solar radiation for the same area; optimize the used area by the solar cells and its integration technology into the PV module is the main factor for maximize the power density [30].

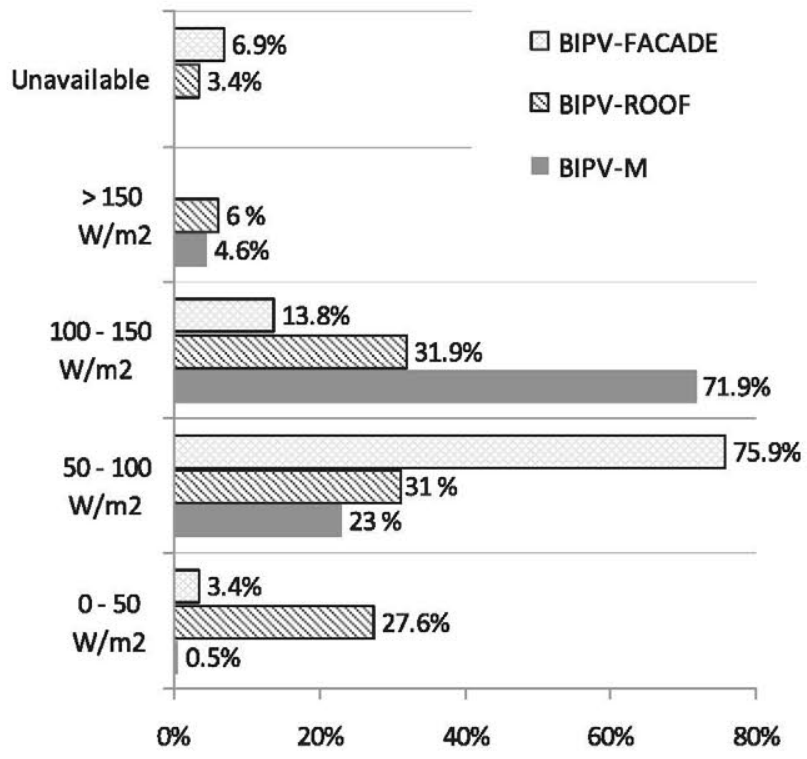

Fig. 5. Power density $\left(\mathrm{W} / \mathrm{m}^{2}\right)$ of BIPV modules, BIPV roofs and BIPV facades.
Secondly, most of solar cells used nowadays have a high efficiency between $14 \%$ and $19 \%$ which corresponds to crystalline silicon technology. Some of BIPV-M which are made up in Si-mono (Sun Power and ET Solar), and HIT (Sanyo) produce more than $150 \mathrm{~W} / \mathrm{m}^{2}$.

In general, increasing integration features produces a directly proportional decrease in the power conversion efficiency, which is evident in PV-CE: complex geometry, wasting of solar gain area, the use of thin-film technology and a lot of variation in solar cells' properties e.g. color and transparency.

\subsection{Guarantee and safety of BIPV elements}

Quality standards related to design qualification and type approval for flat-plate PV modules are EN-IEC 61215 for crystalline

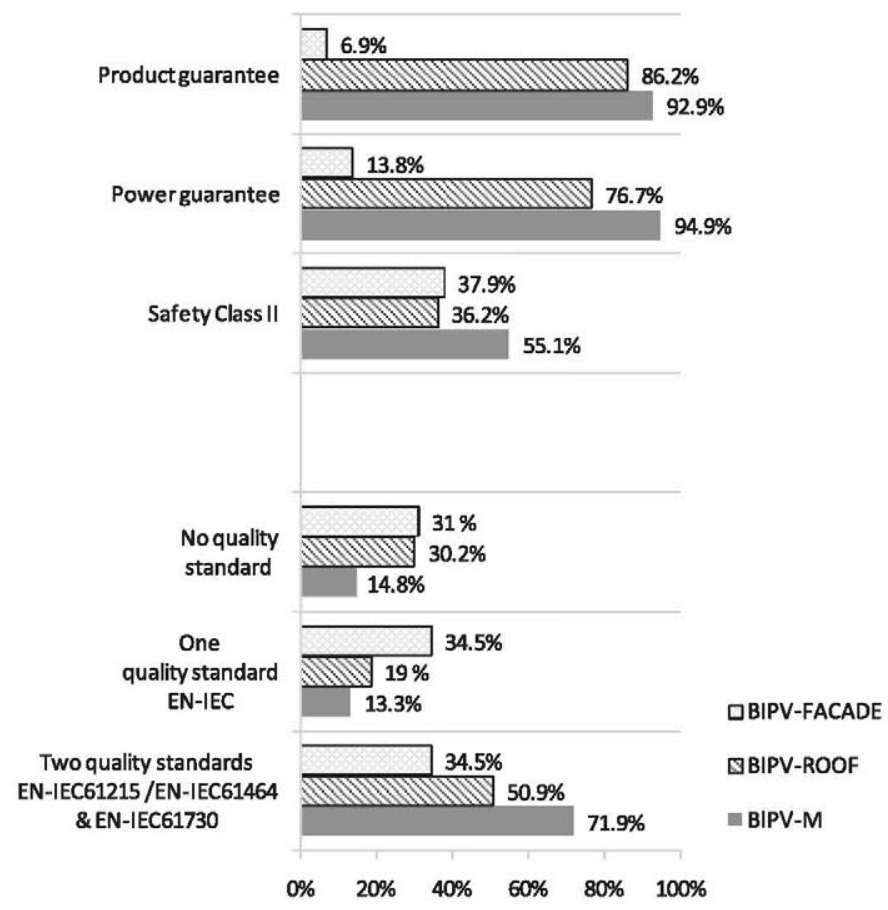

Fig. 6. Guarantees and safety of BIPV modules, BIPV roofs and BIPV facades. 


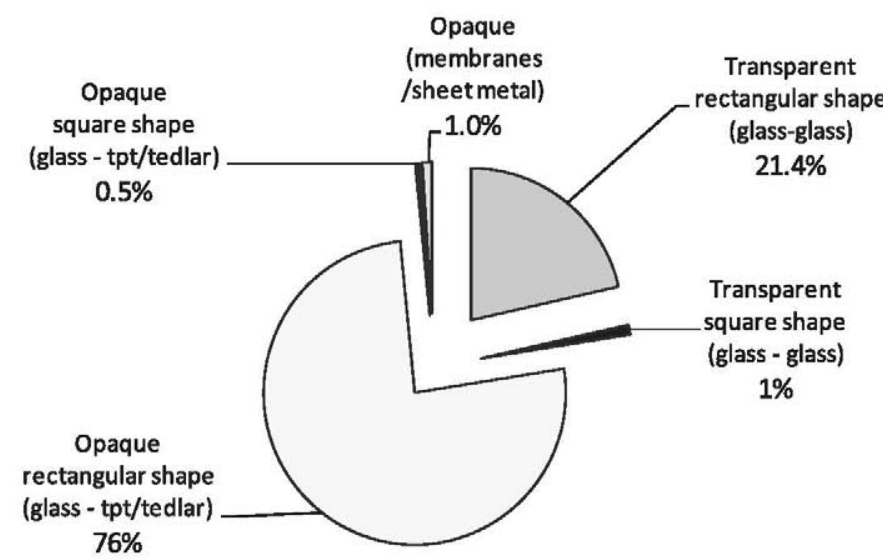

Fig. 7. Appearance and composition of the BIPV-Modules. (a)

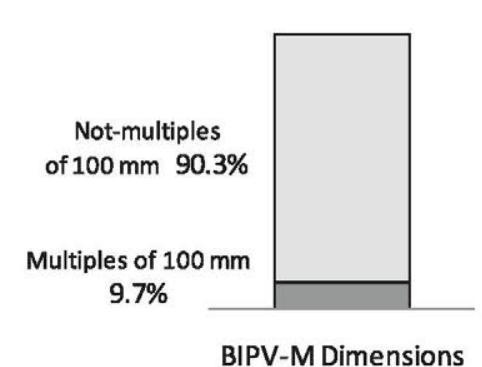

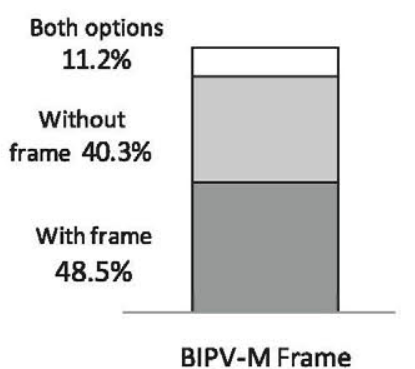

(b)
Fig. 8. Dimensions (a) and mounting systems (b) of BIPV modules.

Silicon technologies (mono-crystalline and multi-crystalline) [31] and EN-IEC 61646 for thin-film technologies [32]. Moreover, the standard EN-IEC 61730 describes the constructive requirements that PV modules must meet in order to guarantee electrical and mechanical safety $[33,34]$. Safety Class II means, equivalent degree of insulation reinforced Class II that it is recommended if the system voltage exceeds $120 \mathrm{~V}$.

By the other hand, it is well known that some hidden defects of PV systems only appear in normal operation, and rarely detected in reliability testing (EN-IEC61215 and EN-IEC61646) [35], consequently some manufacturers typically provides a power guarantee in which a maximum power is guaranteed after a number of years (the most common is: $90 \%$ after the first 10 years and $80 \%$ at 25 years of operation). Unlike PV-CE, this practice is usual among BIPV-M marketers as shown in Fig. 6, in this sense, the most likely option would be to require suppliers all warranties of their products [36].

In addition, product guarantees aims to ensure the correct functionality of the products by a minimum of years, so according to European Directive on Construction Products the minimum time should be 2 years [6]. Regarding BIPV elements, companies must guarantee their products by a minimum of 5 years and it is a trend in this study. Some BIPV-M marketers have extended the products warranty to 10 years.

\section{Architectural analysis}

\subsection{Formal perspective}

\subsubsection{BIPV-modules}

To determine why the PV modules manufacturers consider some products for architectural integration is a difficult matter due to the limited information found about the peculiarities of these products. The evaluation of the quality information provided by the suppliers is very subjective, for this reason, in this study, all the BIPV-M qualitative information related to aesthetics, composition, sizes, and mechanical characteristics criterions are compiled. In this sense, two years ago, the market was clearly oriented to semitransparent modules [26], but the decline in use of thin-film technology and the tendency to make custom design, has changed the market' orientation. Nowadays, most BIPV-M are opaque and rectangular shaped (glass - tedlar-polyester-tedlar called 'tpt'/tedlar configuration), see Fig. 7.

Although the building materials do not have dimensions prescribed, the architects and builders prefer modulated elements. For this reason, the dimensions that are multiples of $100 \mathrm{~mm}$ are really interesting in this study. As Fig. 8, 90.3\% of BIPV-M has dimensions different as well. Mounting systems are another outstanding characteristic which defines the safety and the appearance of the integration. The study points out the use of universal mounting systems made of aluminum [37].

\subsubsection{PV - constructive elements}

There are several ways to identify opportunities for integration of BIPV elements [38]. One of these is the element function that is conditioned by the location in the building envelope, we identified two groups: roofing elements and facade elements. These elements are designed from the beginning to sort out and improve the support structure issues, the modularity and flexibility of integration.

As shown in Fig. 9, more than 57\% of BIPV roofing systems are solar tiles, this is due to most experience on BIPV has been carried out at Northern Europe where the tile is a typical roofing system. In addition, on the other hand, tiles are elements of simple geometry;

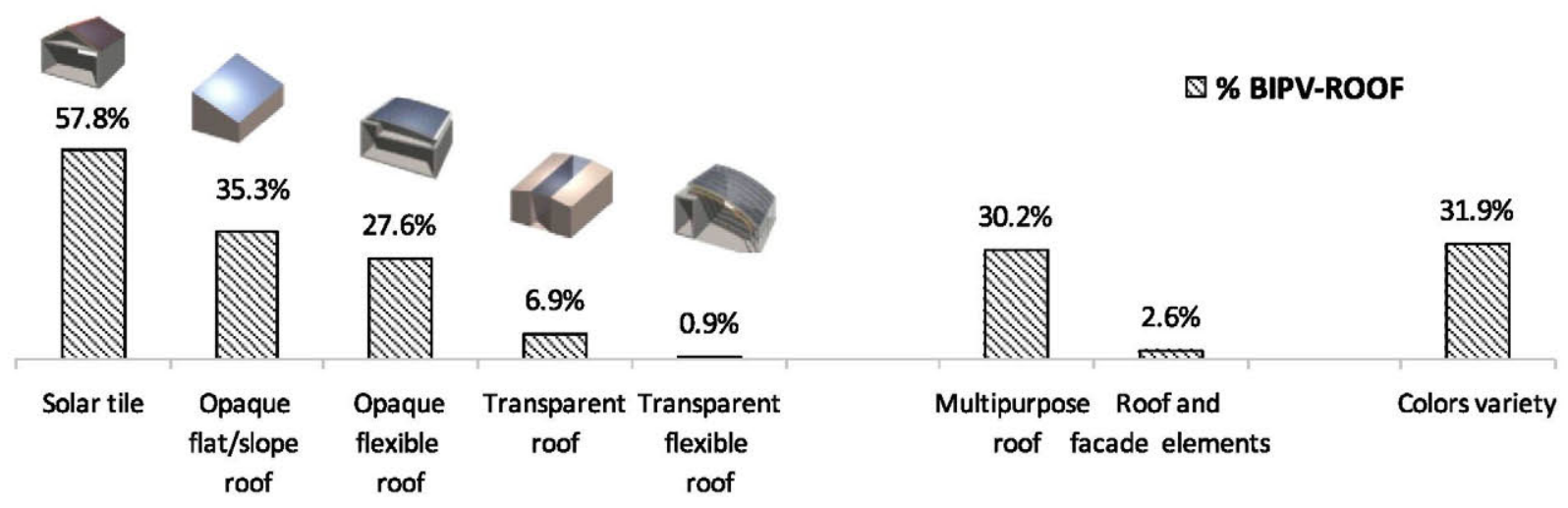

Fig. 9. Formal aspect to BIPV roofing. 


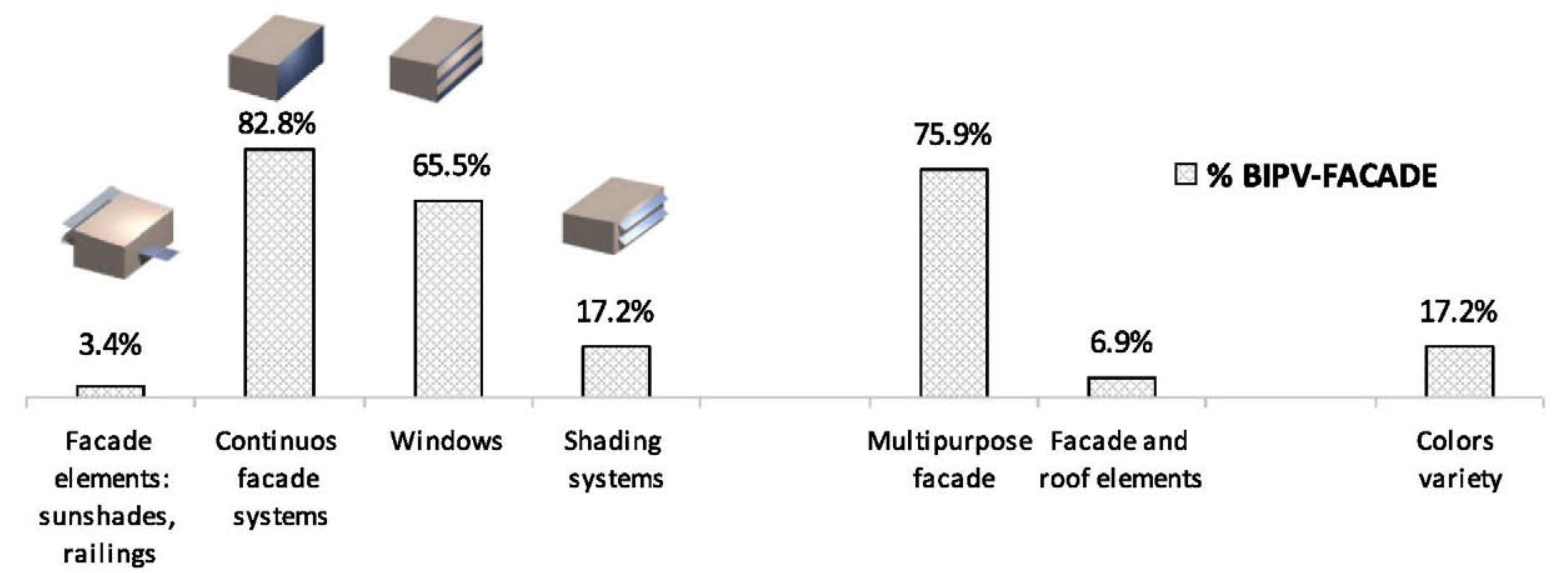

Fig. 10. Formal aspect to BIPV facade.

they have been integrated with solar cells with independence of the development of PV technology. Also, it is striking that, although tiles is the most common constructive elements it is not in terms of installed power due to their complex installation and their high cost. Waterproofing PV constructive elements designed for opaque flat-plat and sloped roofs represents more than $35 \%$ of the products, and flexible opaque elements $27 \%$. Only $6 \%$ of roof transparent PV elements, generally used in skylights and atriums, these are sold in a standard way. Flexibles transparent/translucent elements which consist of structural inflating membranes (a technology that is new in the construction industry) represents near to $1 \%$. PV constructive elements fitting different roof types constitute $30 \%$ of the products, whereas $2 \%$ can be mounted without distinction on roofs as well as on facades.

Regarding to facade elements, during of design many factors are not common in all systems (dimensions, thickness, appearance, insulation, etc.), reason why there are several custom manufactured as opposed to industrial manufacturing, therefore, there is little supply in facade systems, e.g. railings, sunshades and shading systems. Fig. 10 shows that $82.8 \%$ of the results are continuous facade systems followed by $65.5 \%$ of windows systems. $75.9 \%$ of

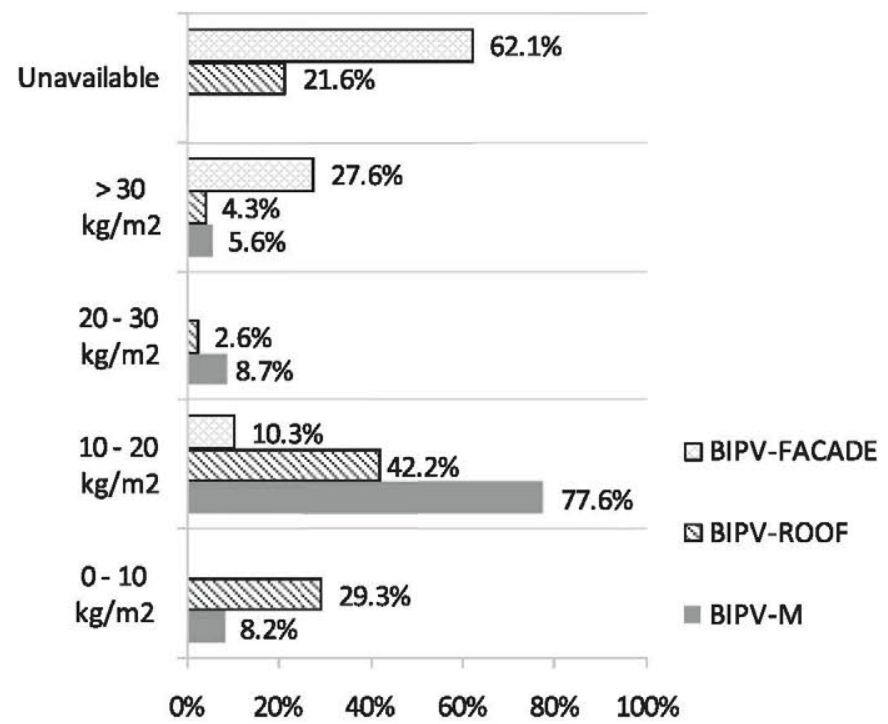

Fig. 11. Weight per unit surface $\left(\mathrm{kg} / \mathrm{m}^{2}\right)$ BIPV modules, BIPV roof and BIPV facade.
BIPV facade systems are multipurpose facade and 17.2\% have several colors.

\subsection{Weight}

PV system integration must mean a suitable overload on the support structure of the building. Most of the PV constructive elements and BIPV modules are under $20 \mathrm{~kg} / \mathrm{m}^{2}$ (see Fig. 11). BIPV roofing are lighter than BIPV facade, as well as, conventional building materials (for example: $20-30 \mathrm{~kg} / \mathrm{m}^{2}$ for conventional tiles in contrast to $60-80 \mathrm{~kg} / \mathrm{m}^{2}$ for Glass Fibre Reinforced Cement, GRC panel sandwich).

\section{Conclusions}

This paper has provided an analytical study of BIPV elements currently used in the BIPV market. 445 products have been reviewed and identified in two main groups, BIPV modules and PV constructive elements, which their more important features are concluded below.

1) BIPV modules, manufacturing by PV industry with physical and/ or aesthetical characteristics of interest from an architectural perspective. $44 \%$ of the surveyed are BIPV modules, where multi-crystalline Silicon is the most used technology with a range of power density between $100 \mathrm{~W} / \mathrm{m}^{2}$ and $150 \mathrm{~W} / \mathrm{m}^{2}$. Regarding aesthetical aspects, the main typology of BIPV modules consists of opaque/rectangular shape (glass-'tpt'/tedlar based composition), with dimensions (length, width and height) different to multiples of $100 \mathrm{~mm}$, and average weight of $20 \mathrm{~kg} / \mathrm{m}^{2}$. In terms of mechanical characteristics, frameless modules represent slightly more than $48 \%$ of the market.

2) PV constructive elements themselves are more innovative in terms of design and architectural functionality, which can be classified according their use in: BIPV roofing, BIPV facade, BIPV urban furniture and BIPV custom design. BIPV roofing elements are the most common, among these stand out solar tiles with a large variety of colors and the use of mono-crystalline Silicon technology. There are fewer products for BIPV facade and the supply usually is made as custom design, among these products the use of amorphous Silicon technology on continuous surfaces, opaque or translucent is the main trend. In terms of weight is generally higher in BIPV facade than in BIPV roofing: typical values under $30 \mathrm{~kg} / \mathrm{m}^{2}$ can be found. Detailed information about support and fixing systems are usually included. 
The BIPV urban furniture is the application which has experienced an increased growth over the past two years, and most products of BIPV custom design have been focused on solar glass.

In addition, the BIPV products have usually $90 \%$ of power guarantee during first 10 years, and $80 \%$ of power guarantee during first 25 years, also it is common to find 5 years of product guarantee.

Although an increasing number of BIPV products can be found, looking to the future, collaboration between the photovoltaic and construction industries must be reinforced in order to develop innovative and attractive products, easy to installation, reliable, with low environment impact and cost-effective. In particular, new developments of PV technologies are needed to enable the integration into several materials that make up the skins of buildings today, easy application of PV cells in conventional materials is imperative because that, in a lot of ways, will allowing the development of new solutions.

\section{Appendix ASupplementary data}

Supplementary data related to this article can be found at http://dx.doi.org/10.1016/j.renene.2013.02.013.

\section{References}

[1] Eiffert P, Kiss GJ. Building-integrated photovoltaic designs for commercial and institutional structures. In: A sourcebook for architect. U.S. Department of Energy's (DOE's) Office of Power Technologies, Photovoltaic Division, and the Federal Energy Management Program. NREL/BK-520-25272. http://www1. eere.energy.gov/femp/pdfs/25272.pdf; February 2000 [accessed 10.05.12].

[2] Erge T, Hoffmann VU, Kiefer K. The German experience with grid-connected PV-systems. Solar Energy 2001;70(6):479-87. http://dx.doi.org/10.1016/ S0038-092X(00)00143-2.

[3] BDPV: Base de Données PhotoVoltaïque, http://www.bdpv.fr/ [accessed 13.03.12].

[4] Jahn U, Nasse W. Operational performance of grid-connected PV systems on buildings in Germany. Progress in Photovoltaics September 2004;12(6):441-8. http://dx.doi.org/10.1002/pip.550.

[5] Changhai P, Ying H, Zhishen W. Building-integrated photovoltaic (BIPV) in architectural design in China. Energy and Buildings December 2011;43(12): 3592-8. http://dx.doi.org/10.1016/i.enbuild.2012.04.003.

[6] Official Journal of the European Communities, Council Directive 89/106/EEC of 21 December 1988 on the approximation of laws, regulations and administrative provisions of the Member States relating to construction products, http://eur-lex.europa.eu/LexUriServ/LexUriServ.do?uri=OJ:L:1989:040:0012: 0026:EN:PDF [accessed 01.05.12].

[7] Henemann A. BIPV: built-in solar energy. Renewable Energy Focus December 2008:9(6. Suppl.):14-9. http://dx.doi.org/10.1016/S1471-0846(08)70179-3.

[8] TASK 7 of the IEA PV power systems program - achievements and outlook. In: Task 7 IEA, conference proceedings: 17th European photovoltaic solar conference. Munich 24 October 2001. http://www.task7.org/Public/17theupvsec/ paper_task7_17th_eu_pvsec.pdf.

[9] España. 'Código Técnico de la Edificación'. DB-HE 5, Apartado 2.2, numeral 5. 2010. ISBN: 84-340-1631-1.

[10] Portolan dos Santosa I, Rüther R. The potential of building-integrated (BIPV) and building-applied photovoltaic (BAPV) in single-family, urban residences at low latitudes in Brazil. Energy and Buildings July 2012;50:290-7. http:/ dx.doi.org/10.1016/i.enbuild.2012.03.052.

[11] Mercaldo LV, Addonizio ML, Della Noce M, Delli Veneri P, Scognamiglio A Privato $C$. Thin film silicon photovoltaics: architectural perspectives and technological issues. Applied Energy October 2009;86(10):1836-44. http:// dx.doi.org/10.1016/j.apenergy.2008.11.034.

[12] Bloema J, Lodib C, Ciprianoc J, Chemisanab D. An outdoor test reference environment for double skin applications of building integrated photovoltaic systems. Energy and Buildings July 2012;50:63-73. http://dx.doi.org/10.1016/ j.enbuild.2012.03.023.
[13] Market survey on solar modules. Magazine Photon International, vol. 2. 2012.

[14] Research Center Switzerland, ISAAC-DACD-SUPSICH-6952, http://www.bipv. ch/index.php?option $=$ com content\&view $=$ article\&id $=75 \&$ ltemid $=4 \&$ lang $=$ en [accessed 15.04.12].

[15] Database for PV applications in the construction, http://www.pvdatabase.org [accessed 20.04.12].

[16] Salón internacional de la ventana y el cerramiento acristalado VETECO. Feria de Madrid IFEMA. May 8-11 2012.

[17] Feria internacional de energía y medio ambiente GENERA. Feria de Madrid IFEMA. May 23-25 2012.

[18] Strong S. Building integrated photovoltaic (BIPV), web page: whole building design guide. National Institute of Buildings Sciences. http://www.wbdg.org/ resources/bipv.php; 27 December 2012 [accessed 18.03.12]

[19] Green World Investor. BIPV solar explained - building integrated photovoltaic glass (efficiency), curtain wall, windows and technology, 14 August 2011 [accessed 04.04.12].

[20] Luque A, Hegedus S. Handbook of photovoltaic science and engineering. Edit. John Wiley \& Sons Inc; 2010. ISBN: 978-0471491965.

[21] Martín CN, Fernández SI. La Envolvente Fotovoltaica en la Arquitectura. Edit. Reverté; 2007.

[22] Henze N, Glotzbach T, Misara S, Roos M, Schulz B. Characterization of photovoltaic modules for building integration, Published by Fraunhofer Institute. Results of multielement project, http://www.iwes.fraunhofer.de/de/ publikationen0/uebersicht/publikationen_veroeffentlichungengesamt/2011/ charactrerisationofphotovoltaicmodulesforbuildingintegration/_jcr_content/ pressrelease/linklistPar/download/file.res/Chacterisation\%20of\% 20photovoltaic\%20modules\%20for\%20building\%20integration.pdf [accessed 10.04.12].

[23] PV in non building structures - a design guide, task 7. Report IEA PVPS T7-02: 2000, http://www.task7.org/public/nbs/23 NBS final.pdf; April 2001.

[24] Roth M, Mayor Newsom and MTA cut ribbon on new solar bus shelters, http:// sf.streetsblog.org/2009/05/29/mayor-newsom-and-mta-cut-ribbon-on-newsolar-bus-shelters/.

[25] Paridaa B, Iniyanb S, Goicc R. A review of solar photovoltaic technologies. Renewable and Sustainable Energy Reviews April 2011;15(3):1625-36. http://dx.doi.org/10.1016/j.rser.2010.11.032.

[26] Cerón I, Olivieri L Caamaño E, Neila FJ. State of the art of BIPV market. In: Proceedings conference: V energy forum on solar buildings skins. Bressanone 02nd-03rd December, 2010.

[27] Siemer J. It's a long way down - price trends for c-Si modules showed a decrease of more than 40 percent in 2011 - and the slide continues. Magazine Photon International February 2012:64.

[28] Bahaj AbuBakr S. Photovoltaic roofing: issues of design and integration into buildings. Renewable Energy May 2003;28(14):2195-204. http://dx.doi.org/ 10.1016/S0960-1481(03)00104-6.

[29] Roecker C. In: Conference proceedings: the 2 nd world solar electric buildings conference. New mounting systems for PV on buildings. Sydney 8th-10th March 2000.

[30] Green MA, Emery K, Hishikawa Y, Warta W, Dunlop ED. Solar cell efficiency tables (version 39). Progress in Photovoltaics January 2012;20(1):12-20. http://dx.doi.org/10.1002/pip. 2163.

[31] European Committee for Electrotechnical Standardization. Crystalline silicon terrestrial photovoltaic (PV) modules. Design qualification and type approval, EN IEC61215. Geneva, Switzerland: Central Office; 2005.

[32] European Committee for Electrotechnical Standardization. Thin-film terrestrial photovoltaic (PV) modules - design qualification and type approval. Standard EN IEC 61646. Geneva, Switzerland: International Electrotechnical Commission, (IEC). Central Office; 2008.

[33] European Committee for Electrotechnical Standardization, Standard EN 61730-1:2007/A1:2012: Photovoltaic (PV) module safety qualification - part 1: requirements for construction, International Electrotechnical Commission, (IEC). Central Office, Geneva, Switzerland. Availability on February 2012.

[34] European Committee for Electrotechnical Standardization, EN 61730-2:2007: Photovoltaic (PV) module safety qualification - part 2: requirements for testing, International Electrotechnical Commission, (IEC). Central Office, Geneva, Switzerland. Availability on May 2007.

[35] Munoz MA, Alonso-Garcia MC, Nieves V, Chenlo F. Early degradation of silicon PV modules and guaranty conditions. Solar Energy September 2011;85(9): 2264-74. http://dx.doi.org/10.1016/i.solener.2011.06.011.

[36] Fernandez P. Considerations for selecting thin-film technologies for largescale photovoltaic applications. Online Journal PV-Tech.org. http://www.pvtech.org; 1 May 2009 [accessed 03.12.10].

[37] Mounting system of PV modules: www.solrif.com, by company: www. schweizer-metallbau.ch [accessed 10.06.12].

[38] Roberts S, Guariento N. Building integrated photovoltaic a handbook. ISBN: 978-3-764-9948-1. Basel, Switzerland 2009. 